\title{
KONSELING REALITAS UNTUK MENINGKATKAN PENERIMAAN DIRI PADA ANAK DI USIA SEKOLAH DASAR
}

Oleh:

Hardiyanti Rahmah

Sekolah Tinggi Ilmu Alquran (STIQ) Amuntai, Kalimantan Selatan

\begin{abstract}
Abstrak
Anak yang mengalami permasalahan psikologis, seperti masih belum bisa menerima keadaan dirinya ketika mengalami suatu masalah, sehingga membuat anak mengalami rasa rendah diri yang membuat dia menarik diri dari lingkungannya. Untuk meningkatkan kembali kemampuan anak dalam menerima kondisi dirinya saat ini, maka diberikan intervensi berupa konseling realitas. Pengumpulan data dilakukan dengan observasi, wawancara dan penggunaan tes psikologi. Hasil penelitian ini menunjukkan adanya perubahan positif dari anak berupa meningkatnya penerimaan diri anak terhadap kondisinya saat ini sehingga mampu aktif kembali dalam beradaptasi di lingkungan rumah dan sekolahnya.

Kata kunci :Konseling Realitas, Penerimaan Diri, Usia Anak
\end{abstract}

\section{A. Pendahuluan}

Pada masa anak-anak merupakan masa pencarian jati diri dan masa-masa yang penuh dengan gejolak. Salah satu tugas perkembangan pada masa anak-anak yaitu persiapan menghadapi masa dewasa, pembelajaran pada masa anak adalah belajar dari lingkungan pergaulan, namun anak masih belum mampu untuk memahami dengan bijaksana terhadap pengalaman apa saja yang dia dapatkan. Permasalahan yang menyangkut masa depan adalah pendidikan, pekerjaan, perkawinan, kegiatan mengisi waktu luang, keluarga, dan aktualisasi diri. Hal yang paling diminati anak adalah pendidikan dan pekerjaan. Orientasi masa 
Hardiyanti Rahmah: Konseling Realitas untuk Meningkatkan Penerimaan Diri pada Anak di Usia Sekolah Dasar

depan dapat dipengaruhi oleh lingkungan dimana dia berada. Suasana baru atas pindahnya tempat tinggal yang cukup jauh akan menyebabkan anak menyalahkan dirinya sendiri dan cenderung inferioritas karena merasa sulit atau tidak nyaman dalam beradaptasi di lingkungan baru.

Hasil penelitian yang dilakukan pada seorang anak yang mengalami masalah menunjukkan bahwa terapi realitas memiliki pengaruh yang positif pada kesehatan mental mereka, terapi realitas pada penelitian ini diketahui dapat mengurangi depresi, kegelisahan dan rasa stress. ${ }^{1}$

Berdasarkan penelitian-penelitian yang telah dilakukan sebelumnya, maka pemberian terapi realitas pada anak yang memiliki penerimaan diri rendah, akan dapat membawa perubahan yaitu meningkatnya penerimaan diri anak tersebut ke arah yang lebih baik. Pada dasarnya terapi realitas merupakan sebuah terapi yang menekankan pada pentingnya kualitas pribadi, menghormati diri sendiri dan penerimaan diri yang positif. ${ }^{2}$

Penerimaan diri yang rendah juga didasari karena kurangnya rasa tanggung jawab, serta karena patokan dari nilai norma antara benar dan salah yang keliru.Pendekatan Glesser melalui teori realitas menekankan pada masalah moral antara benar dan salah yang harus dihadapkan kepada konseli sebagai kenyataan atau realitas. Sehingga dengan adanya intervensi berupa konseling realitas diharapkan dapat menekankan pertimbangan menyangkut nilai-nilai. ${ }^{3}$

\footnotetext{
${ }^{1}$ Massah, O., Farmani, F., Karimi, R., Karami,H., Hoseini, F., Farhouidian, A. Group reality therapy in addicts rehabilitation process to reduce depression, anxiety and stress. (Iranian Rehabilitation Journal. 13,1, 2015) h. 44-50

${ }^{2}$ Masson, C.P.\& Duba, J.D. Using reality therapy in schools: Its potential impact on the effectiveness of the ASCA national mode. (International Journal of Reality Therapy. 29,1, 2009) h. 5-12

${ }^{3}$ Nelson. R., \& Jones. Teori dan praktik konseling dan konseling. (pentrj. Helly Prajitno Soetjipto \& Sri Mulyantini Soetjipto) (Yogyakarta: Pustaka Pelajar, 2011).
} 
Hardiyanti Rahmah: Konseling Realitas untuk Meningkatkan Penerimaan Diri pada Anak di Usia Sekolah Dasar

\section{B. Kajian Teoritis}

\section{Konseling Realitas}

Konseling Realitas adalah suatu sistem yang difokuskan pada tingkah laku sekarang. Konseling berfungsi sebagai guru dan model serta mengonfrontasikan anak dengan cara-cara yang bisa membantu anak menghadapi kenyataan dan memenuhi kebutuhan-kebutuhan dasar tanpa merugikan dirinya sendiri ataupun orang lain.

Pendekatan menggunakan konseling realitas berfokus pada tingkah laku di masa sekarang. Meskipun tidak menganggap perasaan dan sikap tidak penting, tetapi konseling realitas menekankan kesadaran atas tingkah laku sekarang. Konseling realitas adalah proses pengajaran (teaching process) dan bukan proses penyembuhan (healing process). Itu sebabnya konseling realitas sering menggunakan pula pendekatan kognitif dengan maksud agar konseli dapat meneyesuaikan diri terhadap realitas yang dihadapinya. ${ }^{4}$

Glasser beranggapan bahwa perilaku yang tidak bertanggungjawab dari seorang konseli sebagai penyebab permasalahan sebenarnya. Manusia harusnya bertanggungjawab untuk percaya pada kebenaran yang akan menghasilkan perilaku yang bertanggungjawab yang akan menyediakan baginya makna, pengharapan dan kasih yang berfungsi sebagai penuntun kepada hidup yang lebih efektif dengan orang lain sebagaimana dengan dirinya sendiri. ${ }^{5}$

Konseling Realitas menguraikan prinsip-prinsip dan prosedur-prosedur yang dirancang untuk membantu orang-orang dalam mencapai suatu "identitas keberhasilan", dapat diterapkan psikokonseling, konseling, pengajaran dan lainnya. Konseling Realitas adalah suatu bentuk modifikasi tingkah laku, karena dalam penerapan-penerapan institusionalnya, merupakan tipe pengondisian operan yang tidak ketat.

2011)

${ }^{4}$ Palmer, S. Konseling dan Psikokonseling. (Yogyakarta: Pustaka Pelajar,

${ }^{5}$ Nelson. R., \& Jones. Teori dan praktik konseling dan konseling... 
Hardiyanti Rahmah: Konseling Realitas untuk Meningkatkan Penerimaan Diri pada Anak di Usia Sekolah Dasar

Konseling realitas merupakan suatu sistem yang difokuskan pada tingkah laku sekarang. Konselor berfungsi sebagai guru dan model serta mengkonfrontasi anak dengan cara-cara yang bisa membantu anak menghadapi kenyataan dan memenuhi kebutuhan-kebutuhan dasar (kebutuhan untuk kelangsungan hidup, mencintai dan dicintai, kekuasaan/kekuatan, kebebasan serta kesenangan) tanpa merugikan dirinya sendiri ataupun orang lain. ${ }^{6}$

\section{Penerimaan Diri}

Individu yang mampu menerima kualitas kemanusiaannya tanpa menyalahkan diri sendiri untuk kondisi yang berada di luar kontrolnya merupakan individu yang memiliki penerimaan diri yang baik. Individu dengan penerimaan diri yang tinggi tidak peduli akan berapa banyak kelemahan yang dimilikinya, justru menjadikan kelemahan tersebut sebagai sumber kekuatan untuk memaksimalkan terhadap diri sendiri. ${ }^{7}$

Untuk memiliki penerimaan diri yang baik, maka individu tersebut harus memiliki pemahaman tentang dirinya sendiri. Mengetahui apa yang menjadi kelebihan dan kemampuan pada dirinya, sehingga dia bisa mengembangkan sikap positif terhadap dirinya sendiri.

Penerimaan diri berdasarkan pada kepuasan atau kebahagiaan individu mengenai dirinya, serta berfikir mengenai kebutuhannya untuk memiliki mental yang sehat. Penerimaan diri merupakan tingkat dimana individu benar-benar mempertimbangkan karakteristik pribadinya dan mau hidup dengan karakteristik tersebut. Dengan penerimaan diri individu dapat menghargai segala kelebihan dan kekurangan dalam dirinya. ${ }^{8}$

${ }^{6} \mathrm{Kim}, \mathrm{J} . \mathrm{U}$. The effect of a reality therapy group counseling program on the internet addiction level and self-esteem of internet addiction university students. (International Journal of Reality Therapy, 27, 2, 2008) h. 4-13

${ }^{7}$ Hurlock, E. B. Personality development. (Tokyo: McGraw-Hill Publishing Company, 1978)

${ }^{8}$ Hurlock, E. B. Psikologis perkembangan: Suatu pendekatan sepanjang rentang kehidupan. (Jakarta : Erlangga, 1999) 
Hardiyanti Rahmah: Konseling Realitas untuk Meningkatkan Penerimaan Diri pada Anak di Usia Sekolah Dasar

Selain itu, penerimaan diri adalah sikap yang pada dasarnya merasa puas dengan diri sendiri, kualitas diri, dan pengakuan akan keterbatasanketerbatasan diri. Penerimaan diri dalam hal ini mengandung makna bahwa individu bisa menghargai segala aspek yang ada pada dirinya, baik itu yang bersifat positif maupun yang bersifat negatif. ${ }^{9}$

\section{Metode Penelitian}

Desain penelitian ini menggunakan teknik studi kasus, yang digunakan untuk menguji efektivitas dari hasil terapi ${ }^{10}$. Studi kasus adalah metode pengumpulan data yang integratif yaitu menggunakan beragam teknik pendekatan dan bersifat komprehensif yaitu data yang dikumpulkan meliputi seluruh aspek pribadi individu secara lengkap ${ }^{11}$. Data yang didapat dari studi kasus meliputi studi yang hati-hati dan interpretasi data yang berhubungan dengan perkembangan dan masalah serta rekomendasi yang tepat ${ }^{12}$.

Subjek pada penelitian ini hanya 1 orang dan berjenis kelamin laki-laki, dengan usia 11 tahun, saat ini subjek belum mau bersekolah di tempat baru dan mengalami sakit karena masalah yang dialaminya, subjek merasa orangtuanya pindah ke tempat baru karena sikapnya yang tidak baik ditempat sebelumnya.

Adapun metode pengumpulan data yang dilakukan terdiri dari beberapa cara yaitu, Observasi, interview dan penggunaan alat tes psikologi. Observasi dilakukan pada saat anak beraktivitas sehari-hari, observasi dilakukan dengan menggunakan observasi partisipan.Tujuannya adalah untuk melihat perilaku anak dalam segala situasi.

Wawancara dilakukan dengan anak (autoanamnesa) dan juga keluarga anak (alloanamnesa),yang bertujuan untuk mengumpulkan data-data terkait

\footnotetext{
${ }^{9}$ Chaplin, J. P. Kamus lengkap psikologi. Penerjemah : Kartini Kartono. (Jakarta :PT Raja Grafindo Persada, 2011)

${ }^{10}$ Creswell, J. W. Research design: Pendekatan Kualitatif, kuantitatif dan mixed.(Jogjakarta: Pustaka Pelajar, 2010).

${ }^{11}$ Moleong, J. L. Metodologi penelitian kualitatif.(Bandung: PT Remaja Rosdakarya, 2014).

${ }^{12}$ Widdowson, M. Case study research methodology.(International Journal of Transactional Analysis Research, 2, 1, 2011). h. 25-34
} 
Hardiyanti Rahmah: Konseling Realitas untuk Meningkatkan Penerimaan Diri pada Anak di Usia Sekolah Dasar

dengan anak. Tes psikologi diberikan pada anak dalam upaya menemukan pola perilaku dan pola pemikiran yang mencerminkan fungsi kepribadian anak yang belum terungkapkan. ${ }^{13}$ Adapun beberapa tes psikologi yang digunakan yaitu tes grafis yang diberikan terdiri dari 3 macam yaitu, Draw A Person (DAP), BAUM dan House Tree Person (HTP). Pemberian tes grafis bertujuan untuk menganalisis kepribadian yang komprehensif dari kepribadian mulai dari dinamikanya hingga sindrom-sindrom klinis yang terproyeksi dari masingmasing objek gambar.

\section{Skema terbentuknya Masalah}

Stressor: Masa anak yang kurang dikontrol oleh orang tua, sehingga bebas dalam melakukan berbagai hal, seperti berteman tanpa kenal waktu, bebas mengakses sosial media tanpa pengawasan, serta kepindahan tiba-tiba yang

membuat anak merasa terpaksa beradaptasi lagi dilingkungan lain dan batasan-batasan yang diterapkan secara langsung oleh orang tua di tempat yang baru sehingga suasana tempat tinggal dirasakan anak sebagai hukuman.

Kerentanan Psikologis: Kepribadian tertutup, mudah terpengaruh, ragu-ragu dalam mengambil keputusan, merasa terabaikan.

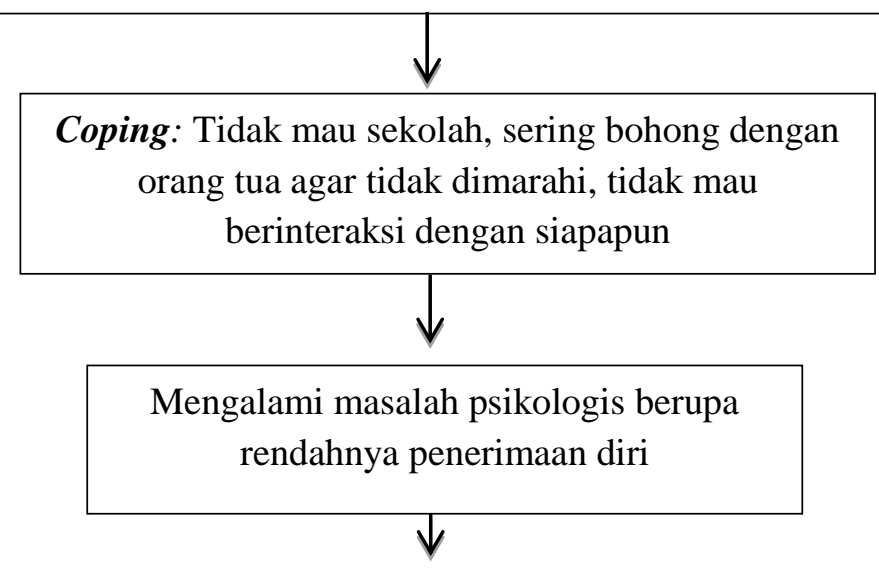

${ }^{13}$ Anastasi, A \& Urbina, S. Tes psikologi. (pentrj. Robertus H.S Imam) $\left(7^{\text {ed }}\right.$ ).

(Jakarta: PT Indeks, 2007)

Al-Madrasah: Jurnal Ilmiah Pendidikan Madrasah Ibtidaiyah

Vol. 4, No. 1, Juli-Desember 2019 
Hardiyanti Rahmah: Konseling Realitas untuk Meningkatkan Penerimaan Diri pada Anak di Usia Sekolah Dasar

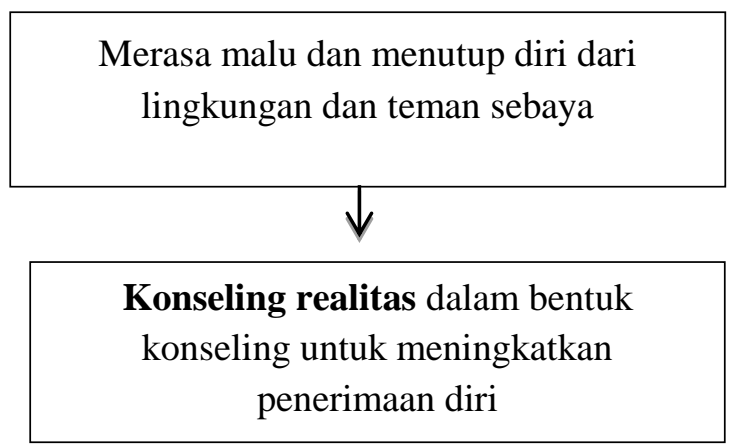

\section{Hasil Penelitian}

Dari penelitian yang telah dilakukan, anak mengalami masalah atau problem psikologis. Anak masih belum mampu menerima kondisinya yang terbiasa hidup di kota besar dan up to date dengan beragam sosial media dengan teman-teman yang menurutnya sudah sangat akrab, kemudian terpaksa ikut pindah ke daerah yang tidak semenarik di kota besar dan dibatasi orang tuanya akses elektronik karena merasa anak yang sudah sangat ketergantungan dengan teknologi dan internet, sehingga anak akhirnya merasa menjadi sumber penyebab kepindahannya ke tempat yang tidak nyaman menurutnya dan anak cenderung menutup diri dan hanya mau berinteraksi dengan orang tertentu saja bahkan menolak untuk sekolah. Sehingga anak mengalami permasalahan berupa penurunan terhadap penerimaan pada dirinya sendiri.

Anak merasa menjadi sumber masalah orangtuanya sehingga mereka tidak lagi tinggal di tempat sebelumnya dan harus pindah begitu jauh. Karena perasaan bersalah itu anak akhirnya menutup diri dan sangat sulik diajak berinteraksi ataupun berkomunikasi, bahkan menolak bersekolah di tempat baru, padahal menurut orangtuanya anaknya termasuk anak yang cukup aktif dulunya, namun kadang sulit untuk diberikan batasan atau mentaati aturan yang diberikan orangtua, sehingga orangtua merasa anak harus diarahkan agar bisa lebih baik lagi dalam mentaati aturan yang diberlakukan kepadanya baik tentang waktu berteman ataupun tentang penggunaan internet. 
Hardiyanti Rahmah: Konseling Realitas untuk Meningkatkan Penerimaan Diri pada Anak di Usia Sekolah Dasar

Perasaan bersalah yang muncul ini membuat anak menjadi rendah rasa penerimaan dirinya dan akhirnya sering menyalahkan dirinya sendiri atas segala hal negatif yang terjadi. Baik merasa orang tua tidak peduli, teman-teman akrabnya mengabaikan dan sulit untuk menghargai dirinya sendiri.

Berdasarkan hasil asessmen yang mengungkapkan bahwa anak sulit untuk menerima keputusan yang diambil oleh orang lain untuk dirinya, maka konseling realitas yang didasari pada teori pilihan ini diharapkan mampu membantu anak. Terutama untuk menyadari kondisi dirinya saat ini bahwa ada alasan yang baik dan positif atas keputusan keluarganya dan batasan terhadap sikap anak yang selau bermain internet agar dia bisa lebih banyak berinteraksi dengan segala hal di dunia nyata. Sehingga akhirnya dapat membantu anak untuk menerima kondisi dirinya saat ini.

Dengan diberikannnya konseling realitas anak diharapkan lebih mampu menerima bahwa dia harus beradaptasi di lingkungan baru dan memulai interaksi baru, serta menerima batasan yang dilakukan orangtuanya terhadap dirinya antara dunia nyata dan dunia internet. Konseling Realitas adalah suatu sistem yang difokuskan pada tingkah laku sekarang. Konseling berfungsi sebagai guru dan model serta mengonfrontasikan anak dengan cara-cara yang bisa membantu anak menghadapi kenyataan dan memenuhi kebutuhankebutuhan dasar tanpa merugikan dirinya sendiri ataupun orang lain.

Teknik yang digunakan pada konseling realitas ini terdiri dari beberapa teknik, yaitu, menggunakan role playing dengan konseli, menggunakan humor yang mendorong suasana yang segar dan tenang, tidak menjanjikan kepada konseli maaf apapun, karena terlebih dahulu diadakan perjanjian untuk melakukan perilaku tertentu yang sesuai dengan keberadaan anak. Selain itu, menolong konseli untuk merumuskan perilaku tertentu yang akan dilakukannya, membuat model-model peranan konselor sebagai guru yang lebih bersifat mendidik, membuat batas-batas yang tegas dari struktur dan situasi konselingnya dan menggunakan konseling kejutan verbal untuk mengkonfrontasikan konseli. Adapun tahapan konseling terdiri dari: 
Hardiyanti Rahmah: Konseling Realitas untuk Meningkatkan Penerimaan Diri pada Anak di Usia Sekolah Dasar

\section{Pra konseling:}

Sesi 1 dan 2 : Anak menerima kontrak kerja dan mengidentifikasi perilaku yang diharapkan serta arah perubahan.

\section{Konseling:}

Sesi 3 : Menanyakan anak terkait keinginannya saat ini, kebutuhan, persepsi dan tingkat komitmennya. Kemudian mengeskplorasi tindakan, pikiran dan perasaan anak.

Sesi 4 : Mendorong anak untuk menerima dan memperoleh keadaan nyata dan merangsang anak untuk mampu mengambil keputusan sendiri.

Sesi 5 : Menumbuhkan tanggung jawab, sehingga keputusan terakhir berada di tangan anak.

Sesi 6 : Mengarahkan anak untuk mampu mengevaluasi diri sendiri.

Sesi 7 : Anak diminta membuat rencana tindakan yang dipilih oleh anak dan sepenuhnya dapat dikontrol oleh anak.

Sesi 8 : Meringkas percakapan, rumusan langkah pertama dan dukungan terhadap rencana tindakan yang akan dilakukan anak dan melakukan terminasi.

\section{Pasca Konseling}

Sesi 9 : Mengetahui perkembangan anak terhadap kemampuannya dalam mempraktekkan rencana-rencana yang sudah anak tentukan sebelumnya.

Berdasarkan dari konseling realitas untuk meningkatkan penerimaan diri pada anak, hasilnya cukup positif dan dapat dilihat munculnya insight pada anak. Saat pertama kali bertemu konselor, anak banyak menutup dirinya, bahkan anak sempat tidak mau menjawab ketika ditamya tentang kondisi keluarganya dan pekerjaan orang tuanya.

Setelah beberapa kali pertemuan dalam sesi konseling anak mulai memunculkan insight dan mulai mengembangkan pikirannya ke arah yang lebih postif dibandingkan sebelumnya.Adapun hasil perubahan yang tampak pada diri anak setelah diberikan konseling realitas ada pada tabel berikut: 
Hardiyanti Rahmah: Konseling Realitas untuk Meningkatkan Penerimaan Diri pada Anak di Usia Sekolah Dasar

Tabel 1. Hasil Intervensi

\begin{tabular}{|c|l|l|}
\hline No & \multicolumn{1}{|c|}{ Sebelum } & \multicolumn{1}{|c|}{ Sesudah } \\
\hline $\mathbf{1}$ & $\begin{array}{l}\text { Anak tidak dapat menerima } \\
\text { bahwa saat ini harus berada di } \\
\text { lingkungan yang baru dan } \\
\text { terpisah dari teman-teman lama } \\
\text { sehingga menolak sekolah di } \\
\text { tempat baru }\end{array}$ & $\begin{array}{l}\text { Anak dapat menerima kenyataan } \\
\text { bahw orangtuanya memang } \\
\text { harus pindah dan mau mulai } \\
\text { membuka diri untuk masuk } \\
\text { sekolah baru }\end{array}$ \\
\hline $\mathbf{2}$ & $\begin{array}{l}\text { Anak merasa dirinya tidak } \\
\text { berguna dan hanya memiliki } \\
\text { hal-hal buruk saja }\end{array}$ & $\begin{array}{l}\text { Anak menyadari bahwa dirinya } \\
\text { memiliki potensi-potensi positif } \\
\text { yang dapat dikembangkan baik } \\
\text { saat di sekolah yang dulu ataupun } \\
\text { di sekolah yang baru }\end{array}$ \\
\hline $\mathbf{3}$ & $\begin{array}{l}\text { Anak lebih memandang sisi } \\
\text { negatif yang ada pada dirinya } \\
\text { dari pada kelebihan yang } \\
\text { dimilikinya (seperti merasa } \\
\text { menjadi anak yang tidak } \\
\text { pandai dan dibenci temannya) }\end{array}$ & $\begin{array}{l}\text { Anak dapat melihat sisi positif } \\
\text { yang ada pada dirinya dan mulai } \\
\text { belajar berpikir lebih positif dari } \\
\text { sebelumnya. }\end{array}$ \\
\hline $\mathbf{4}$ & $\begin{array}{l}\text { Anak tidak dapat mengambil } \\
\text { pembelajaran dari kejadian } \\
\text { yang dialaminya }\end{array}$ & $\begin{array}{l}\text { Anak dapat mengambil pelajaran } \\
\text { dari lingkungan barunya dan } \\
\text { melihat sisi positif dalam } \\
\text { beradaptasi }\end{array}$ \\
\hline $\mathbf{5}$ & $\begin{array}{l}\text { Anak merasa tidak } \\
\text { dibanggakan oleh orang } \\
\text { tuanya, karena dia merasa } \\
\text { sering menimbulkan banyak } \\
\text { masalah }\end{array}$ & $\begin{array}{l}\text { Anak menyadari besarnya kasih } \\
\text { sayang orang tuanya, karena tetap } \\
\text { mendukung dan memotivasinya. }\end{array}$ \\
\hline
\end{tabular}

\section{E. Pembahasan}

Seseorang memiliki penerimaan diri positif apabila dia telah mampu belajar untuk dapat menerima hidupnya dan menerima kelebihan serta kekurangan dirinya. Individu yang dapat menerima dirinya ditunjukkan dengan perilaku menghormati dirinya sendiri, memiliki kepercayaan diri, menyadari sisi negatif yang ada pada dirinya. Individu yang tidak dapat menerima dirinya 
Hardiyanti Rahmah: Konseling Realitas untuk Meningkatkan Penerimaan Diri pada Anak di Usia Sekolah Dasar

maka ia tidak akan menyukai karakteristik diri mereka, merasa diri tidak berguna dan tidak percaya diri. ${ }^{14}$

Pada penelitian yang membahas tentang efektivitas konseling realitas untuk meningkatkan efikasi diri pada anak pengguna narkoba, menunjukkan dampak yang signifikan, bahwa konseling realitas dampat lebih meningkatkan efikasi diri pada anak pengguna narkoba. Melebihi konseling kognitif. ${ }^{15}$

Pada penelitian yang menguji efektivitas konseling realitas dalam meningkatkan efikasi diri pada siswi anak menunjukkan bahwa, konseling realitas mampu meningkat efikasi diri pada siswi dengan signifikan. ${ }^{16}$

Pada penggunaan konseling realitas ini, anak menujukkan pada wawasan dan pemahaman yang positif tentang perubahan kepada penerimaan kondisi dirinya secara apa adanya. Anak memahami bahwa dia tidak hanya memiliki kekurangan, tapi juga kelebihan. Sehingga anak mampu menerima keadaan dirinya secara baik. Anak juga menyadari apa yang dia lakukan selama ini adalah hal yang negatif dan mampu memahami alasan harus beradaptasi lagi di lingkungan baru bukan karena kesalahannya sehingga orangtuanya marah tapi karena orangtuanya memang harus pindah.

Menurut terapi realitas pembentukan identitas individu masing-masing dari mengembangkan keterlibatan-keterlibatan dengan orang lain dan dengan banyangan diri yang dengannya diri bisa merasa berhasil atau tidak berhasil. Orang lain memainkan peranan yang berarti dalam membantu individu menjelaskan dan memahami identitasnya sendiri. Cinta dan penerimaan

${ }^{14}$ Ceyhan, A. A. \& Ceyhan, E. Investigation of University Students' Selfacceptance and Learned Resourcefulness: A Longitudinal Study. (High Education. 61, 2011) h 649-661

15 Moghadam, N. A., \& Hosseinifard, S. A. Comparing the impact of cognitive therapy and group reality therapy on self-efficacy of drug abusers in TC Kerman Center circuit treatment. (Jurnal UMP Social Sciences and Technology Management, 3, 13 2015) h. 16-20

${ }^{16}$ Mohammadi, S., Ghamari, M., Jafari, A., \& Nani, Y. M. K.. The effect of group counseling based on reality therapy on self-efficacy of guidance girl students. Journal of Social Issues \& Humanities, 2, 9, 2014) h. 294-298 
Hardiyanti Rahmah: Konseling Realitas untuk Meningkatkan Penerimaan Diri pada Anak di Usia Sekolah Dasar

berkaitan langsung dengan pembentukan identitas. Terapi ini berprinsip bahwa manusia adalah agen yang menentukan dirinya sendiri. ${ }^{17}$

Hasil dari konseling realitas ini menujukkan perubahan pada individu dengan munculnya insight, sehingga meningkatkan kondisi anak yang awalnya memiliki penerimaan diri rendah. Wawasan yang anak dapatkan diharapkan dapat membawa pada perubahan perilaku anak, baik saat anak beradaptasi di lingkungan tempa tinggal barunya atau di sekolah barunya.

\section{F. Kesimpulan}

Konseling realitas yang digunakan berhasil memunculkan insight pada diri anak dan meningkatkan penerimaan dirinya. Sehingga anak mampu untuk mengkondisikan pribadi dan perilakunya ke arah yang lebih baik dari sebelumnya. Anak yang sebelum mengikuti konseling realitas cenderung banyak berpikir negatif tentang dirinya dan selalu mengungkapkan kelemahan yang ada pada dirinya. Setelah mengikuti tahapan dari konseling realitas anak sudah mampu melihat potensi-potensi positif yang ada pada dirinya dan dapat dikembangkan ke arah yang lebih baik.

${ }^{17}$ Wubbolding, R \& Brickell, J. Resources for teaching and learning choice theory and reality therapy, Part II. (International Journal of Choice Theory and Reality Therapy.31, 2, 2012) h. 27-31 
Hardiyanti Rahmah: Konseling Realitas untuk Meningkatkan Penerimaan Diri pada Anak di Usia Sekolah Dasar

\section{Daftar Pustaka}

Anastasi, A \& Urbina, S. (2007). Tes psikologi. (pentrj. Robertus H.S Imam) $\left(7^{\text {ed }}\right)$. Jakarta: PT Indeks.

Ceyhan, A. A. \& Ceyhan, E. (2011). Investigation of University Students' Selfacceptance and Learned Resourcefulness: A Longitudinal Study. High Education. 61, 649-661.

Chaplin, J. P. (2011). Kamus lengkap psikologi. Penerjemah : Kartini Kartono. Jakarta :PT Raja Grafindo Persada.

Corey, G. (2013). Teori dan praktek ponseling \& psikokonseling. (pentrj. E.Koswara). Bandung: Refika Aditama.

Creswell, J. W. Research design: Pendekatan Kualitatif, kuantitatif dan mixed. Jogjakarta: Pustaka Pelajar. 2010.

Hurlock, E. B. (1999). Psikologis perkembangan: Suatu pendekatan sepanjang rentangkehidupan. Jakarta : Erlangga.

Hurlock, E. B. (1978). Personality development. Tokyo: McGraw-Hill Publishing Company.

Kim, J. U. (2008). The effect of a reality therapy group counseling program on the internet addiction level and self-esteem of internet addiction university students.International Journal of Reality Therapy, 27, 2, 4-13.

Massah, O., Farmani, F., Karimi, R., Karami,H., Hoseini, F., Farhouidian, A. (2015). Group reality therapy in addicts rehabilitation process to reduce depression, anxiety and stress.Iranian Rehabilitation Journal. 13, 1, 44-50.

Masson, C.P.\& Duba, J.D. (2009).Using reality therapy in schools: Its potential impact on the effectiveness of the ASCA national mode.International Journal of Reality Therapy. 29,1, 5-12.

Moleong, J. L. Metodologi penelitian kualitatif. Bandung: PT Remaja Rosdakarya. 2014.

Moghadam, N. A., \& Hosseinifard, S. A. (2015). Comparing the impact of cognitive therapy and group reality therapy on self-efficacy of drug abusers in TC Kerman Center circuit treatment. Jurnal UMP Social Sciences and Technology Management, 3, 13, 16-20.

Mohammadi, S., Ghamari, M., Jafari, A., \& Nani, Y. M. K.(2014). The effect of group counseling based on reality therapy on self-efficacy of guidance girl students. Journal of Social Issues \& Humanities, 2, 9, 294-298. ISSN 2345-2633 
Hardiyanti Rahmah: Konseling Realitas untuk Meningkatkan Penerimaan Diri pada Anak di Usia Sekolah Dasar

Nelson. R., \& Jones.(2011). Teori dan praktik konseling dan konseling. (pentrj.

Helly Prajitno Soetjipto \& Sri Mulyantini Soetjipto).(4 $\left.{ }^{\mathrm{ed}}\right)$.Yogyakarta: Pustaka Pelajar.

Palmer, S. (2011). Konseling dan Psikokonseling. Yogyakarta: Pustaka Pelajar.

Wubbolding, R \& Brickell, J. (2012).Resources for teaching and learning choice theory and reality therapy, Part II.International Journal of Choice Theory and Reality Therapy.31, 2, 27-31

Widdowson, M. Case study research methodology.International Journal of Transactional Analysis Research, 2, 1, 25-34, 2011. 